NASA/TM—2014-218122

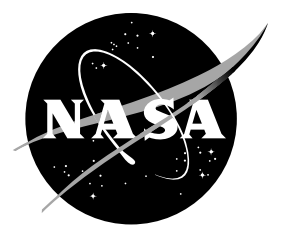

\title{
Multi-Tone Millimeter-Wave Frequency Synthesizer for Atmospheric Propagation Studies
}

Rainee N. Simons and Edwin G. Wintucky

Glenn Research Center, Cleveland, Ohio 


\section{NASA STI Program . . . in Profile}

Since its founding, NASA has been dedicated to the advancement of aeronautics and space science. The NASA Scientific and Technical Information (STI) program plays a key part in helping NASA maintain this important role.

The NASA STI Program operates under the auspices of the Agency Chief Information Officer. It collects, organizes, provides for archiving, and disseminates NASA's STI. The NASA STI program provides access to the NASA Aeronautics and Space Database and its public interface, the NASA Technical Reports Server, thus providing one of the largest collections of aeronautical and space science STI in the world. Results are published in both non-NASA channels and by NASA in the NASA STI Report Series, which includes the following report types:

- TECHNICAL PUBLICATION. Reports of completed research or a major significant phase of research that present the results of NASA programs and include extensive data or theoretical analysis. Includes compilations of significant scientific and technical data and information deemed to be of continuing reference value. NASA counterpart of peer-reviewed formal professional papers but has less stringent limitations on manuscript length and extent of graphic presentations.

- TECHNICAL MEMORANDUM. Scientific and technical findings that are preliminary or of specialized interest, e.g., quick release reports, working papers, and bibliographies that contain minimal annotation. Does not contain extensive analysis.

- CONTRACTOR REPORT. Scientific and technical findings by NASA-sponsored contractors and grantees.
- CONFERENCE PUBLICATION. Collected papers from scientific and technical conferences, symposia, seminars, or other meetings sponsored or cosponsored by NASA.

- SPECIAL PUBLICATION. Scientific, technical, or historical information from NASA programs, projects, and missions, often concerned with subjects having substantial public interest.

- TECHNICAL TRANSLATION. Englishlanguage translations of foreign scientific and technical material pertinent to NASA's mission.

Specialized services also include creating custom thesauri, building customized databases, organizing and publishing research results.

For more information about the NASA STI program, see the following:

- Access the NASA STI program home page at http://www.sti.nasa.gov

- E-mail your question to help@sti.nasa.gov

- Fax your question to the NASA STI Information Desk at 443-757-5803

- Phone the NASA STI Information Desk at 443-757-5802

- Write to: STI Information Desk NASA Center for AeroSpace Information 7115 Standard Drive Hanover, MD 21076-1320 
NASA/TM-2014-218122

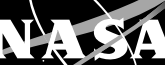

Multi-Tone Millimeter-Wave Frequency Synthesizer for Atmospheric Propagation Studies

Rainee N. Simons and Edwin G. Wintucky

Glenn Research Center, Cleveland, Ohio

Prepared for the

International Symposium on Antennas and Propagation and USNC/URSI National Radio Science Meeting sponsored by the Institute of Electrical and Electronics Engineers

Memphis, Tennessee, July 6-12, 2014

National Aeronautics and

Space Administration

Glenn Research Center

Cleveland, Ohio 44135 


\section{Acknowledgments}

The support from the 2013 NASA GRC Center Innovation Fund (CIF) is gratefully acknowledged.

This report contains preliminary findings, subject to revision as analysis proceeds.

Level of Review: This material has been technically reviewed by technical management.

Available from

NASA Center for Aerospace Information 7115 Standard Drive

Hanover, MD 21076-1320
National Technical Information Service 5301 Shawnee Road Alexandria, VA 22312

Available electronically at http://www.sti.nasa.gov 


\title{
Multi-Tone Millimeter-Wave Frequency Synthesizer for Atmospheric Propagation Studies
}

\author{
Rainee N. Simons and Edwin G. Wintucky \\ National Aeronautics and Space Administration \\ Glenn Research Center \\ Cleveland, Ohio 44135
}

\begin{abstract}
This paper presents the design and test results of a multi-tone millimeter-wave frequency synthesizer, based on a solid-state frequency comb generator. The intended application of the synthesizer is in a space-borne transmitter for radio wave atmospheric studies at Q-band ( 37 to $43 \mathrm{GHz}$ ). These studies would enable the design of robust high data rate space-to-ground satellite communication links.
\end{abstract}

\subsection{Introduction}

The frequency spectrum allocated and utilized currently for satellite communications uplinks and downlinks are rapidly getting congested due to very heavy usage. The logical choice is to move higher up in frequency into the millimeter-wave (mm-wave) frequency bands, which are sparsely used. The mm-wave bands include frequencies in the Q-band (37 to $42 \mathrm{GHz}$ ) and the V/W-band (71 to $76 \mathrm{GHz}$ ). Migrating to the mm-wave frequency bands has the added advantages of smaller antenna size and lower mass for a given spacecraft effective isotropic radiated power (EIRP). In addition, in the case of commercial communications satellites, which use multiple beams to increase throughput, the beamwidth for a given antenna aperture size is smaller at the above mm-wave frequencies. The smaller beamwidth results in a smaller spot size on ground, which allows packing greater number of spot beams over a given area and thus enables greater spectral efficiency through frequency reuse. Prior to system planning and system design for deployment in space, it is essential to investigate the effects of Earth's atmosphere on radio wave propagation at the above frequencies. In general, radio waves suffer increasing attenuation, scintillation, depolarization, and group delay due to atmospheric gases, clouds and rain (Ref. 1).

In this paper, we present the design, construction and test results for a multi-tone frequency synthesizer (Ref. 2) based on the discrete frequency spectrum produced by a high frequency solid-state comb generator. Unlike the single frequency beacon source, which flew on NASA's Advanced Communications Technology Satellite (ACTS) (Ref. 3) for Ka-band propagation experiments (Ref. 4), the multi-tone frequency synthesizer is capable of simultaneously delivering coherent multiple frequencies. These multiple frequencies enable characterizing the frequency dependent group delay effects, which are essential for the design of high data rate wide band satellite communications links.

\subsection{Multi-Tone Frequency Synthesizer Architecture}

\subsection{Multi-Tone Frequency Synthesizer Circuit Design, Construction and Mode of Operation}

A simplified block schematic of the basic multi-tone frequency synthesizer based beacon transmitter that could fly on a geostationary satellite as a hosted payload for radio wave propagation experiments at $\mathrm{mm}$-wave frequencies is presented in Figure 1. The synthesizer consists of a comb generator, which puts out evenly spaced harmonic frequencies of the input signal, which are coherent and tunable over a wide frequency range. These harmonics are then amplified to the power level needed for radio wave propagation studies.

Harmonics that are amplified are simultaneously transmitted as beacon signals from space to receiving ground stations located at several climate zones within the CONUS. By measuring the signal relative strength and phase at ground sites one can estimate the attenuation and group delay or dispersion due to atmospheric induced effects.

\subsection{Rational for a Multi-Band Multi-Tone Frequency Synthesizer Circuit, Design, and Construction}

Significant amount of statistical data has been accumulated since the pioneering ACTS experiments of the 1990's and accurate models that predict the impairments to radio waves in the 20/30 GHz bands due to Earth's atmosphere are available. In addition, communications satellite systems are currently operational at these frequencies. It is also well understood that signals at Q-band and $\mathrm{V} / \mathrm{W}$-band frequencies would experience much higher attenuation during rain fades than signals in the $20 / 30 \mathrm{GHz}$ range. The deep fades will result in poor signal-to-noise ratio at the Q-band and V/W-band beacon receivers on ground, which could cause the receivers to lose frequency/phase lock. To overcome this problem it is desirable to include a coherent K-band (18 to $26.5 \mathrm{GHz}$ ) beacon source along with the Q-band and V/W-band beacon sources on the payload. Because of higher signal-to-noise ratio at K-band, the beacon receiver on ground can retain lock during deep fades and thus enable high availability attenuation measurements or characterization. This data is valuable and can provide a 
reference for model development and also provide an understanding of frequency model scaling factors for future system design when Q-band and V/W-band propagation data is unavailable (Ref. 1).

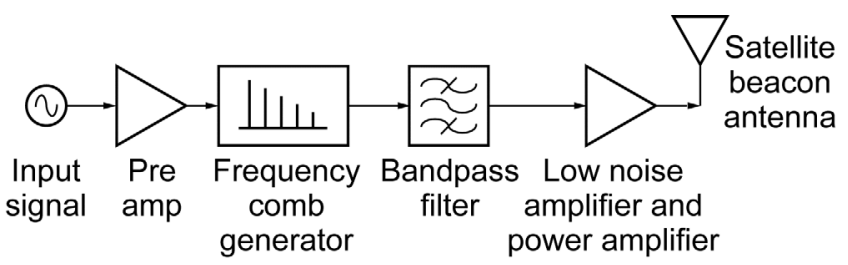

Figure 1.-Schematic block diagram of the basic multi-tone frequency synthesizer based beacon transmitter payload for radio wave propagation experiments.

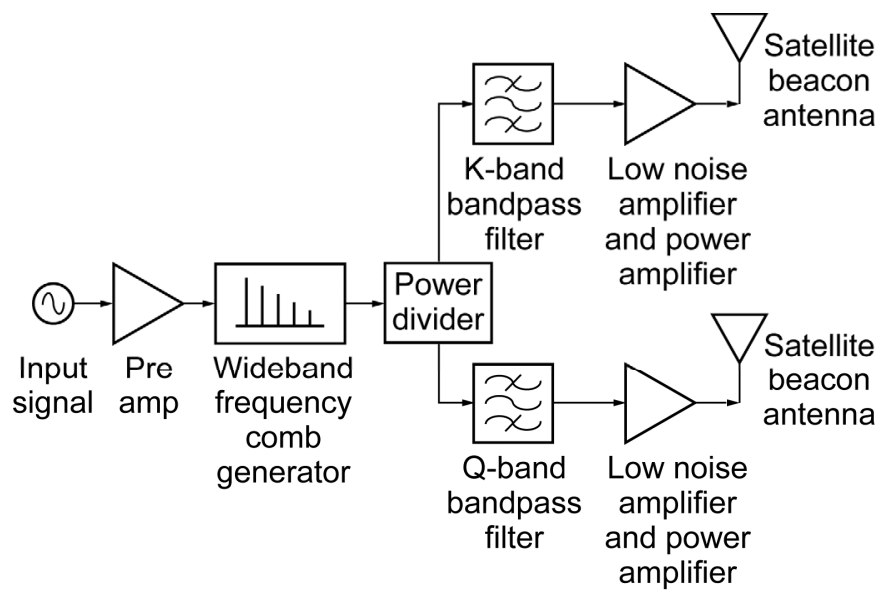

Figure 2.-Schematic block diagram of the multi-band multi-tone frequency synthesizer based beacon transmitter payload for radio wave propagation experiments.
A block schematic of the multi-band multi-tone frequency synthesizer breadboard circuit is presented in Figure 2. The synthesizer consists of a high frequency wideband solid-state comb generator. The K-band and Q-band harmonics are separated by bandpass filters and amplified to the power level required for radio wave propagation studies before transmission.

\subsection{Multi-Tone Frequency Synthesizer Characterization and Test Data}

A generic test setup for characterizing the K-band and the Q-band multi-tone frequency synthesizer circuits described above is presented in Figure 3. Photographs of the K-band and the Q-band test circuit are shown in Figures 4 and 5, respectively. The bandpass filters and the low noise amplifiers (LNAs) are appropriately selected for the two frequency bands. The measured K-band and Q-band spectrums are presented in Figures 6 and 7, respectively. A chain of MMIC based power amplifiers can further enhance the power levels such that the beacon EIRP is on the order of $30 \mathrm{dBW}$ at the edge of CONUS coverage (Ref. 5). A minimum data collection period of 36 months is recommended and hence the above EIRP is the end of life value (Ref. 1).

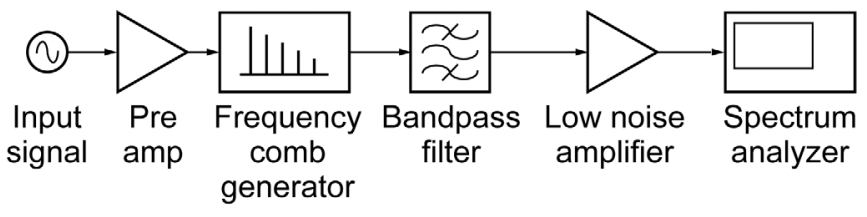

Figure 3.-Test setup for characterizing the multi-tone frequency synthesizer.

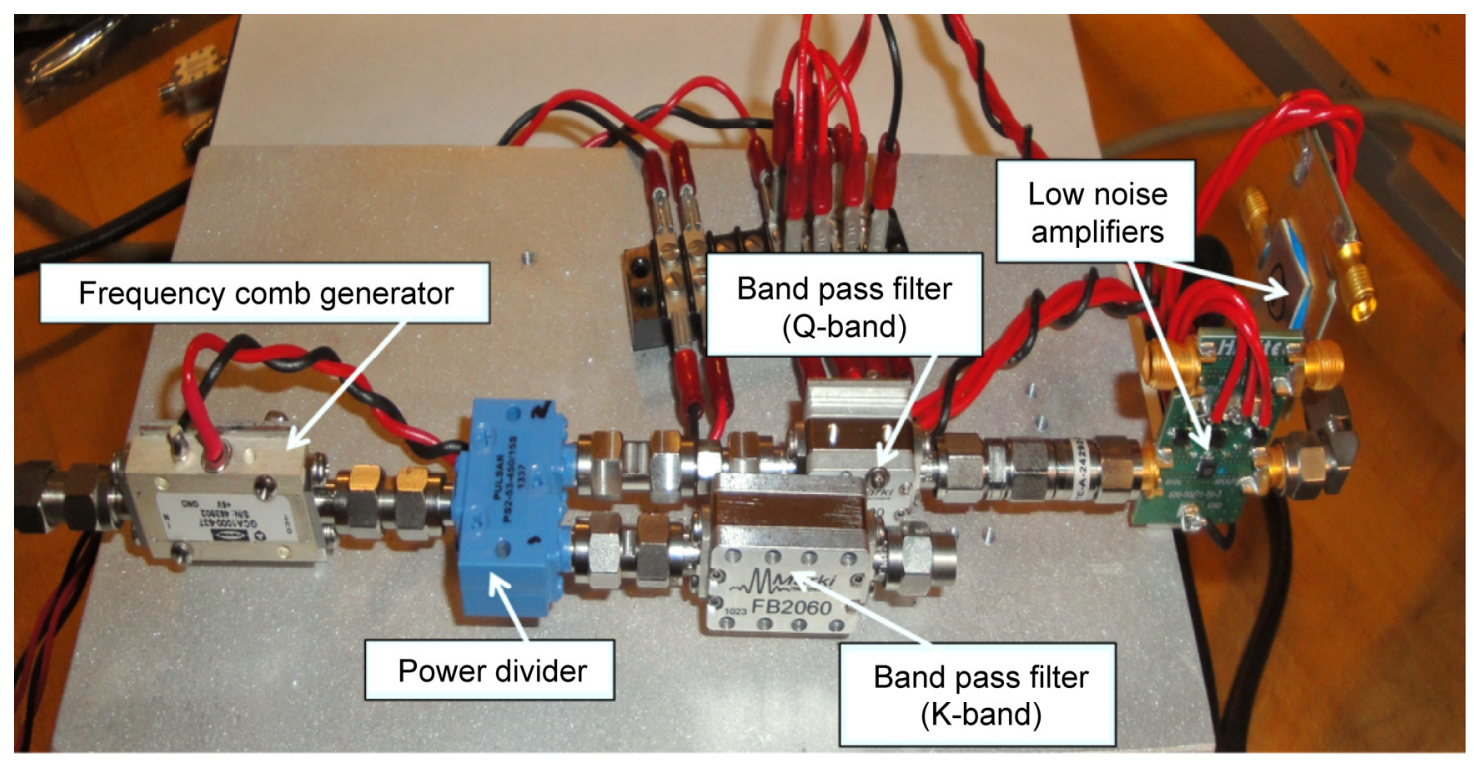

Figure 4.-Test circuit used for measurements at K-band. 


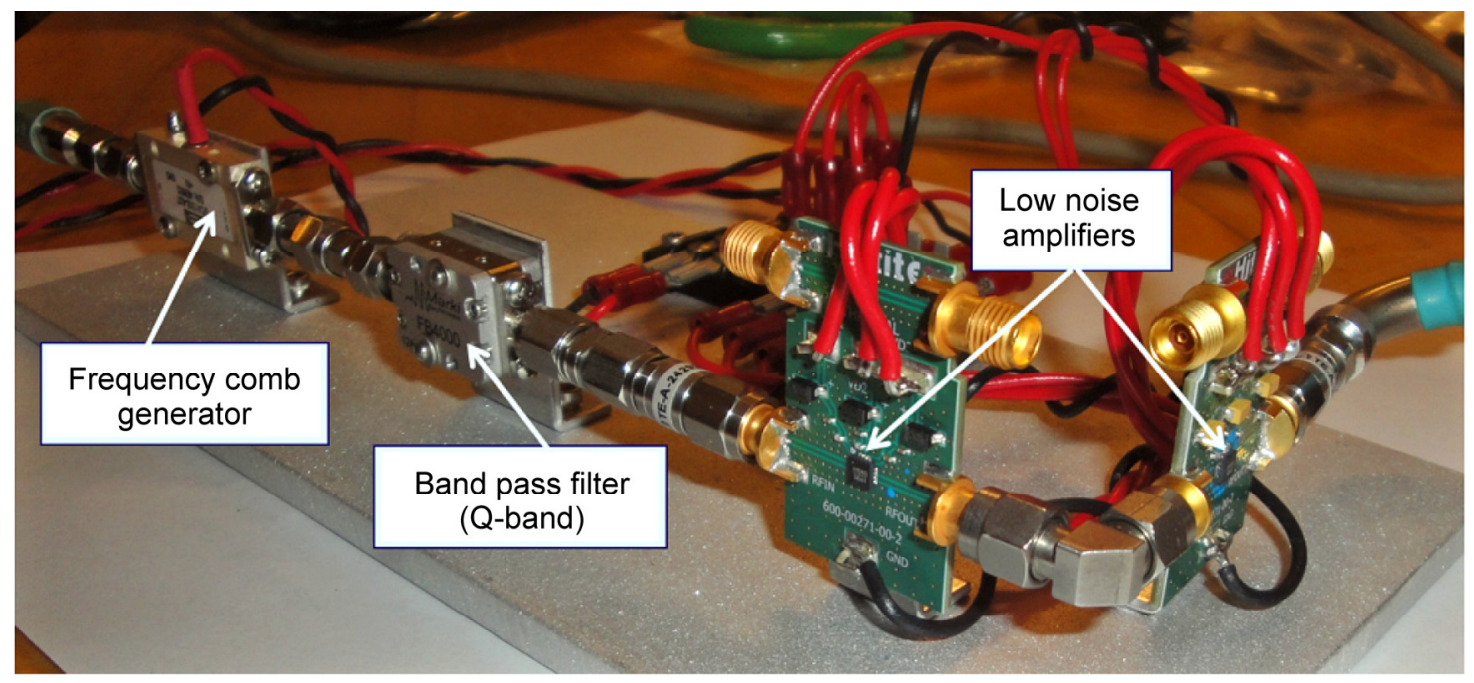

Figure 5.-Test circuit used for measurements at Q-band.

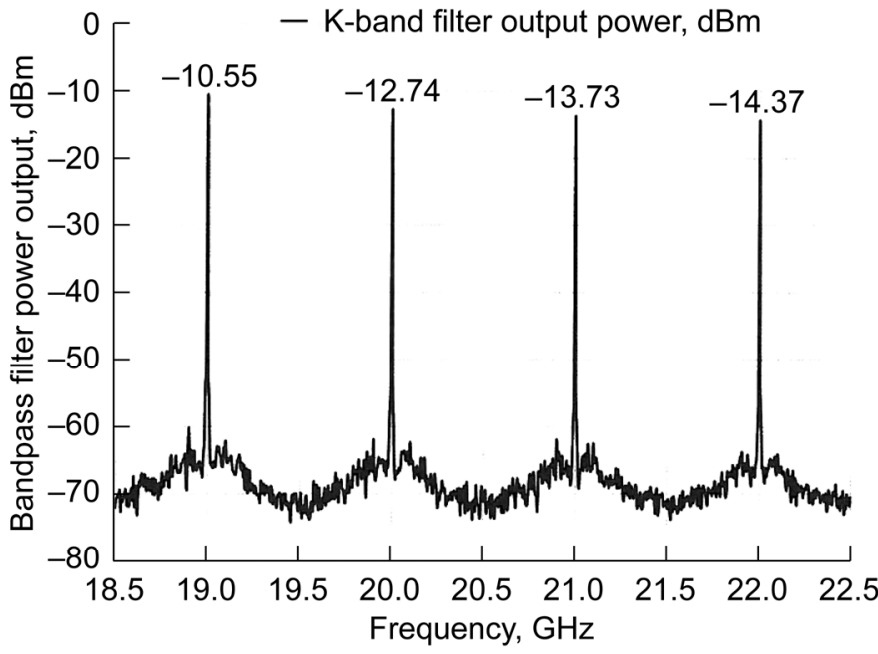

Figure 6.-K-band spectrum as measured at the output of the bandpass filter.

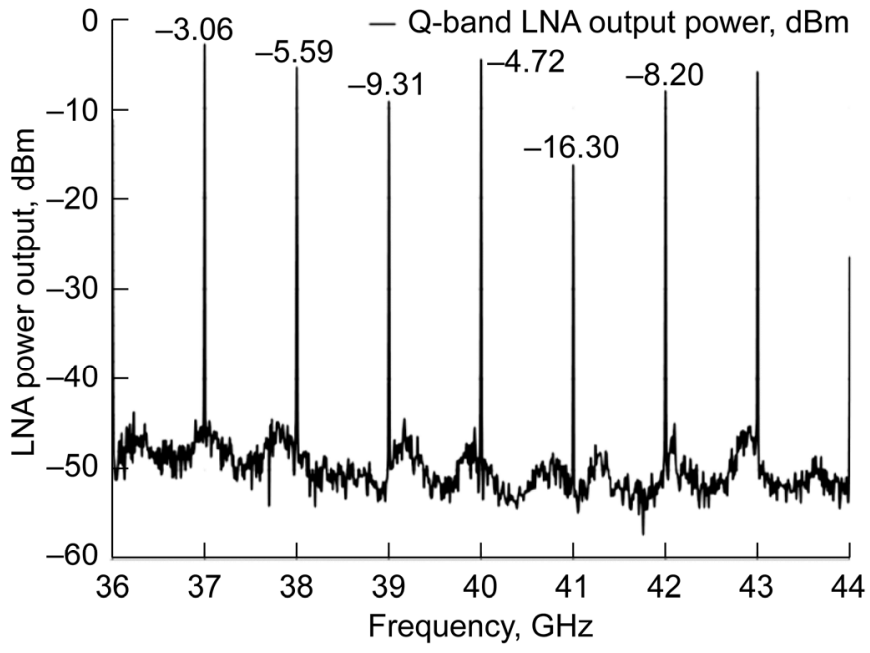

Figure 7.-Q-band spectrum as measured at the output of the low noise amplifier.

\subsection{Conclusions}

The design, construction and test data for a K-band and a Q-band multi-tone frequency synthesizer for radio wave propagation studies are presented.

\section{References}

1. R.J. Acosta, J.A. Nessel, R.N. Simons, M.J. Zemba, J.R. Morse and J. Budinger, "W/V-Band RF Propagation Experiment Design," $18^{\text {th }} \mathrm{Ka}$ and Broadband Communications Navigation and Earth Observation Conference Digest, pp. 355-362, Ottawa, Canada, Sept. 24-27, 2012.

2. Patent Application Filed with the U.S.P.T.O.

3. R. Bauer, "Ka-band Propagation Measurements: An Opportunity with the Advanced Communications Technology Satellite (ACTS)," Proc. IEEE, vol. 85, no. 6, pp. 853-862, June 1997.

4. R.J. Acosta, R. Bauer, R.J. Krawczyk, R.C. Reinhart, M.J. Zernic, F. Gargione, "Advanced Communications Technology Satellite (ACTS): Four-Year System Performance," IEEE Jour. Selected Areas in Communications, vol. 17, no. 2, pp. 193-203, Feb. 1999.

5. R.N. Simons and E.G. Wintucky, "Q-Band (37-41 GHz) Satellite Beacon Architecture for RF Propagation Experiments," 2012 IEEE Antennas and Propagation International Symposium Digest, Chicago, IL, July 8-14, 2012. 


\begin{tabular}{|c|c|c|}
\hline \multicolumn{2}{|c|}{ REPORT DOCUMENTATION PAGE } & $\begin{array}{l}\text { Form Approved } \\
\text { OMB No. 0704-0188 }\end{array}$ \\
\hline \multicolumn{3}{|c|}{ 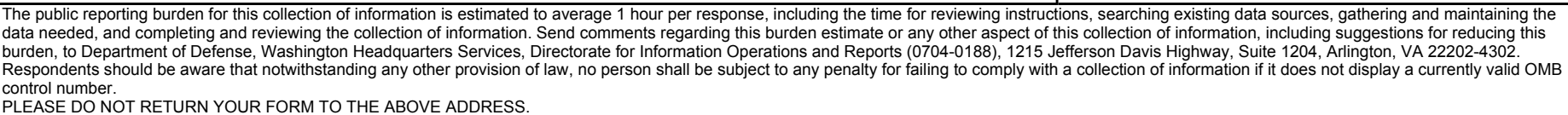 } \\
\hline $\begin{array}{l}\text { 1. REPORT DATE (DD-MM-YYYY) } \\
01-04-2014\end{array}$ & $\begin{array}{l}\text { 2. REPORT TYPE } \\
\text { Technical Memorandum }\end{array}$ & 3. DATES COVERED (From - To) \\
\hline \multirow{3}{*}{\multicolumn{2}{|c|}{$\begin{array}{l}\text { 4. TITLE AND SUBTITLE } \\
\text { Multi-Tone Millimeter-Wave Frequency Synthesizer for Atmospheric Propagation Studies }\end{array}$}} & 5a. CONTRACT NUMBER \\
\hline & & 5b. GRANT NUMBER \\
\hline & & 5c. PROGRAM ELEMENT NUMBER \\
\hline \multirow{3}{*}{\multicolumn{2}{|c|}{$\begin{array}{l}\text { 6. AUTHOR(S) } \\
\text { Simons, Rainee, N.; Wintucky, Edwin, G. }\end{array}$}} & 5d. PROJECT NUMBER \\
\hline & & 5e. TASK NUMBER \\
\hline & & $\begin{array}{l}\text { 5f. WORK UNIT NUMBER } \\
\text { WBS } 295670.01 .04\end{array}$ \\
\hline \multicolumn{2}{|c|}{$\begin{array}{l}\text { 7. PERFORMING ORGANIZATION NAME(S) AND ADDRESS(ES) } \\
\text { National Aeronautics and Space Administration } \\
\text { John H. Glenn Research Center at Lewis Field } \\
\text { Cleveland, Ohio 44135-3191 }\end{array}$} & $\begin{array}{l}\text { 8. PERFORMING ORGANIZATION } \\
\text { REPORT NUMBER } \\
\text { E-18864 }\end{array}$ \\
\hline \multirow{2}{*}{\multicolumn{2}{|c|}{$\begin{array}{l}\text { 9. SPONSORING/MONITORING AGENCY NAME(S) AND ADDRESS(ES) } \\
\text { National Aeronautics and Space Administration } \\
\text { Washington, DC 20546-0001 }\end{array}$}} & $\begin{array}{l}\text { 10. SPONSORING/MONITOR'S } \\
\text { ACRONYM(S) } \\
\text { NASA }\end{array}$ \\
\hline & & $\begin{array}{l}\text { 11. SPONSORING/MONITORING } \\
\text { REPORT NUMBER } \\
\text { NASA/TM-2014-218122 }\end{array}$ \\
\hline \multicolumn{3}{|c|}{$\begin{array}{l}\text { 12. DISTRIBUTION/AVAILABILITY STATEMENT } \\
\text { Unclassified-Unlimited } \\
\text { Subject Category: } 17 \\
\text { Available electronically at http://www.sti.nasa.gov } \\
\text { This publication is available from the NASA Center for AeroSpace Information, 443-757-5802 }\end{array}$} \\
\hline
\end{tabular}

\section{ABSTRACT}

This paper presents the design and test results of a multi-tone millimeter-wave frequency synthesizer, based on a solid-state frequency comb generator. The intended application of the synthesizer is in a space-borne transmitter for radio wave atmospheric studies at Q-band (37 to 43 $\mathrm{GHz}$ ). These studies would enable the design of robust high data rate space-to-ground satellite communication links.

\section{SUBJECT TERMS}

Telecommunications; Space communication; Satellite communications; Microwave transmission

\begin{tabular}{|c|c|c|c|c|c|}
\hline \multicolumn{3}{|c|}{ 16. SECURITY CLASSIFICATION OF: } & \multirow{2}{*}{$\begin{array}{l}\text { 17. LIMITATION OF } \\
\text { ABSTRACT } \\
\text { UU }\end{array}$} & \multirow{2}{*}{$\begin{array}{l}\text { 18. NUMBER } \\
\text { OF } \\
\text { PAGES } \\
10\end{array}$} & \multirow{2}{*}{$\begin{array}{l}\text { 19a. NAME OF RESPONSIBLE PERSON } \\
\text { STI Help Desk (email:help@ } \text { sti.nasa.gov) } \\
\text { 19b. TELEPHONE NUMBER (include area code) } \\
\text { 443-757-5802 }\end{array}$} \\
\hline $\begin{array}{l}\text { a. REPORT } \\
U\end{array}$ & $\begin{array}{l}\text { b. ABSTRACT } \\
U\end{array}$ & $\begin{array}{l}\text { c. THIS } \\
\text { PAGE } \\
\text { U }\end{array}$ & & & \\
\hline
\end{tabular}



